\title{
The Role of Bidara Leaf Extract (Ziziphus Mauritiana) on the Prevention of Renal Hypertension in Wistar Strain Rats
}

\author{
Dian Yuliartha Lestari, Cintantya Pramastri Yuwono, Dani Pratama Febrianto
}

\begin{abstract}
Hypertension is ranked the fourth highest disease in the word. Glomerulosclerosis is the initial lesion from kidney failure in patient with hypertension. Bidara leaves have active flavonoid such as saponins and tannins are thought to prevent an increase in blood pressure and repair glomerulosclerosis. This study to prove the effect of bidara leaf extract to decrease hypertension and to prevent glomerulosclerosis. This study was true experimental with Pre and Post Test Control Group Design. This study used male white rats wistar strain. Sample divided into 5 groups (positive group, treatment group with 3 leveled dose, and medicine-control group) and were being observed in 28 days. Hypertension was measured using tail cuff blood pressure. Glomerulus observed randomly with light microscope in 5 different field of view with $400 x$ magnification and scoring by Sclerosis Index $(S I)$. In the linear regression test had $R^{2}=0,332$ for systolic blood pressure and $R^{2}=0,609$ for diastolic blood pressure. For glomerulosclerosis we found that the highest SI $(369,69)$ was positive control group, while the lowest SI $(84,09)$ was the group with a dose $400 \mathrm{mg} / \mathrm{kg} /$ day. Bidara leaves extract have a significant effect on reduce hypertension and glomerulosclerosis.
\end{abstract}

Keywords : Hypertension, Glomerulosclerosis, Bidara leaves.

\section{INTRODUCTION}

$\mathrm{H}$ ypertension in one of the most common chronic disease [1]. The prevalence of hypertension is $4^{\text {th }}$ in the world [2]. Hypertension complications can reach 9.4 million deaths annually. According to the World Health Organization (WHO) and the International Society of Hypertension (IDH), there are 600 million people with hypertension worldwide, with 3 million dying each year. Seven out of every 10 sufferers do not get adequate treatment [3]. The incidence of hypertension in Indonesia obtained through measurements at the age of $\geq 18$ years is 25.8 percent, the highest in Bangka Belitung island $(30.9 \%)$, and then South Kalimantan province $(30.8 \%)$, East Kalimantan province $(29.6 \%)$ and the last is West Java province (29.4\%)[4].

Hypertension is the second highest cause of kidney failure. Hypertension is the primary diagnosis in the United States. As many as 30,000 individuals in the United States are

Revised Manuscript Received on January 2, 2020.

* Correspondence Author

Dian Yuliartha Lestari*, Pathology Department, Medical Faculty, University of Muhammadiyah Malang, Malang, Indonesia. Email: dianyuliarthalestari@gmail.com

Cyntantya Pramastri Yuwono, Medical Faculty, University of Muhammadiyah Malang, Malang, Indonesia. Email: cintanparamastri@yahoo.co.id

Dani Pratama Febrianto, Medical Faculty, University of Muhammadiyah Malang, Malang, Indonesia. Email: danipratama4@gmail.com

diagnosed with end-stage renal failure caused by hypertension each year and the number continues to increase [5]. Glomerulosclerosis is the initial lesion which most often causes kidneys tissue damaged which causes kidneys failure caused by hypertension [6]-[7].Clinically, glomerulosclerosis causes nephrotic syndrome, which consists of proteinuria, hypoalbuminemia, hypercholesterolemia and peripheral edema [7].

The bidara tree (Ziziphus mauritiana) is a plant of the family Rhamnaceae. Bidara tree originated from India and is now widely obtained in the tropics [8]. Bidara leaf is used in the treatment of indigestion, fever, liver damage and lung disease, but research on bidara leaf is still small [8]-[9]. Leaf bidara contains several biochemical active ingredients such as alkaloids, saponins, tannins, flavonoids, and terpenoids have their respective mechanisms in repairing and preventing the occurrence of glomerulosclerosis $[10,11,12]$.

\section{MATERIALS AND METHODS}

This research is true experimental pre and post test group design. The sample of this study was 25 male rats (Rattus novergicus strain wistar) aged 2-3 months with a body weight of 15-200 grams and healthy. The sample was divided into 5 group: Negative control group, treatment control group $(200 \mathrm{mg} / \mathrm{kgBW} /$ day, $400 \mathrm{mg} / \mathrm{kgBW} /$ day, $800 \mathrm{mg} / \mathrm{kgBW} /$ day) and positive control group (captopril $1.125 \mathrm{mg} / \mathrm{kgBW} /$ day po). All samples were adapted for 7 days then induced hypertension for 14 days. Hypertension induction using prednisone $1.5 \mathrm{mg} / \mathrm{kgBW}+\mathrm{NaCl} 2 \%$. After 14 days, the negative control group continued induction until $28^{\text {th }}$ day, the positive control group continued with captopril $1.125 \mathrm{mg} / \mathrm{kgBW} /$ day po until $28^{\text {th }}$ day, and the treatment groups continued with bidara leaf extract a dose of $200 \mathrm{mg} / \mathrm{kgBW} /$ day, $400 \mathrm{mg} / \mathrm{kgBW} /$ day po for 14 days

\section{A. Measurement of Rat Blood Pressure}

Blood pressure measurements are measured initially before being treated and after being treated. Blood pressure measurement using the Blood Pressure Monitor bran Coda on tail of a white rats. This method allows researchers to find out systolic and diastolic blood pressure

\section{B. Measurement of Glomerulosclerosis}

Glomerulosclerosis assessment was carried out after 28 days. The rats was killed and its kidney organs were taken and paraffin block preparations were made. 
To observe glomerulosclerosis scores using Masson Trichrome (MT) staining. The preparations were observed using a light microscope with a 400x magnification at 5 different random fields and the Sclerosis Index (IS) was determined semi-quantitatively.

The percentage of glomerulosclerosis occupied by the extracellular matrix is scored, starting with 0: $0 \%, 1+: 1-25 \%$, 2+: 26-50\%, 3+: 51-75\%, 4+: 76-100\%. Determine the Sclerosis Index (SI) with the formula: $[(0 \times n 0+1 \times n 1+2 \times n 2+3 \times n 3+4 \times n 4) / n u m b e r$ of glomerulus $] \mathrm{x}$ 100. n0, n1, n2, n3 and $n 4$ were the number of glomerulus with a score of $0,1,2,3$ and 4 [13].

\section{Data Analysis}

To analyzed pre and post experimental blood pressure using a General Linear Model test and linear regression analysis. To analyzed glomerulosclerosis using an ANOVA one-way test and linear regression analysis.

\section{RESULTS AND DISCUSSION}

The results of systole, diastolic blood pressure measurements and index sclerosis of rats in each group can be seen in the table 1 .

Table I: Systole and Diastolic Blood Pressure Results in Each Group

\begin{tabular}{|c|c|c|c|c|}
\hline \multirow{2}{*}{} & \multicolumn{3}{|c|}{ Systolic Blood Pressure } & \multicolumn{2}{c|}{ Diastolic Blood Pressure } \\
\cline { 2 - 5 } & Pre test & Post test & Pre test & Post tes \\
\hline K+ & $130 \pm$ & $130 \pm$ & $91,67 \pm$ & $76,67 \pm$ \\
& 48,86 & 54,11 & 41,18 & 26,76 \\
\hline K- & $132,33 \pm$ & $136,33 \pm$ & $101,33 \pm$ & $108 \pm$ \\
& 44,79 & 73,81 & 47,01 & 72,50 \\
\hline P1 & $158 \pm$ & $114,67 \pm$ & $120 \pm$ & $72 \pm 26,96$ \\
& 24,87 & 24,82 & 27,05 & \\
\hline P2 & $148,33 \pm$ & $114,33 \pm$ & $105,67 \pm$ & $85,33 \pm$ \\
& 27,66 & 41,28 & 24,17 & 44,74 \\
\hline P3 & $152,67 \pm$ & $183 \pm$ & $119 \pm$ & $133,67 \pm$ \\
& 52,78 & 53,25 & 52,82 & 53,29 \\
\hline
\end{tabular}

Note :

$\mathrm{K}+$ : positive control group

$\mathrm{K}-$ : negative control group

$\mathrm{P} 1$ : treatment group with bidara leaf extract $200 \mathrm{mg} / \mathrm{kgBW} /$ day $\mathrm{P} 2$ : treatment group with bidara leaf extract $400 \mathrm{mg} / \mathrm{kgBW} / \mathrm{day}$ $\mathrm{P} 3$ : treatment group with bidara leaf extract $800 \mathrm{mg} / \mathrm{kgBW} /$ day

Tabel II: Results of Sclerosis Index (IS) in Each Group

\begin{tabular}{|c|c|c|c|c|c|c|c|}
\multirow{2}{*}{ Group } & \multicolumn{5}{|c|}{ Field } & Average & IS \\
\cline { 2 - 7 } & $\mathbf{1}$ & $\mathbf{2}$ & $\mathbf{3}$ & $\mathbf{4}$ & $\mathbf{5}$ & & \\
\hline $\mathrm{K}-$ & 3,75 & 3,70 & 3,83 & 3,5 & 3,91 & 3,74 & 369,69 \\
\hline $\mathrm{K}+$ & 2,17 & 1,67 & 0,5 & 1,67 & 2,17 & 1,63 & 196 \\
\hline P1 & 1,75 & 1 & 1,63 & 1,21 & 1,83 & 1,48 & 143,90 \\
\hline P2 & 1,2 & 0,6 & 0,7 & 0,9 & 0,6 & 0,8 & 84,09 \\
\hline P3 & 0,88 & 1,25 & 2 & 1,33 & 0,88 & 1,27 & 135,29 \\
\hline
\end{tabular}

Note :

$\mathrm{K}+$ : positive control group

$\mathrm{K}-$ : negative control group

$\mathrm{P} 1$ : treatment group with bidara leaf extract $200 \mathrm{mg} / \mathrm{kgBW} /$ day $\mathrm{P} 2$ : treatment group with bidara leaf extract $400 \mathrm{mg} / \mathrm{kgBW} / \mathrm{day}$ $\mathrm{P} 3$ : treatment group with bidara leaf extract $800 \mathrm{mg} / \mathrm{kgBW} /$ day
The data above shows that the highest difference in systolic and diastolic blood pressure decrease was found in the P1 group (table 1), the highest Scoring Index was in the negative control group with a sclerosis index of 369.69 and the lowest sclerosis index of 84.09 for the P2 (table 2).

Before conducting data analysis, homogeneity and normality test were performed with a result of $p>0.05$ both blood pressure data and sclerosis index data. The result of analyzing blood pressure data using the general linear model test obtained $\mathrm{p}<0.05$ (table 3 ), which means that there were differences significantly between groups.

Table III: Data analysis with General Linear Model

\begin{tabular}{|l|l|c|}
\hline \multicolumn{2}{|c|}{ Multivariate Tests $^{\mathbf{a}}$} \\
\hline \multirow{3}{*}{ Eroup } & Effect & Sig. \\
\cline { 2 - 3 } & Pillai's Trace & .066 \\
\cline { 2 - 3 } & Wilks' Lambda & .028 \\
\cline { 2 - 3 } & Hotelling's Trace & .015 \\
\cline { 2 - 3 } & Roy's Largest Root & .003 \\
\hline
\end{tabular}

One Way ANOVA test was performed to determine differences between the dose of bidara leaf extract and the number of glomeruloclerosis. Oneway ANOVA test results obtained sig $=0.000$ which means there was a difference significantly between the dose of bidara leaf extract and captopril as a therapy of hypertension against glomerulosclerosis of white rats.

In the linear regression test, there are 3 variables include: Systolic blood pressure with $\mathrm{R}^{2}=0.332$ (figure 1), and diastolic blood pressure with $R^{2}=0.609$ (figure 2 ), and index score glomerulosclerosis with $\mathrm{R}^{2}=0.041$ (figure 3 ). The percentage role of the bidara leaf extract dose in systolic blood pressure was $3.3 \%$, the percentage role of bidara leaf extract dose in diastolic blood pressure was $6 \%$, and the percentage ole of the bidara leaf extract dose in index sclerosis was $40.1 \%$.

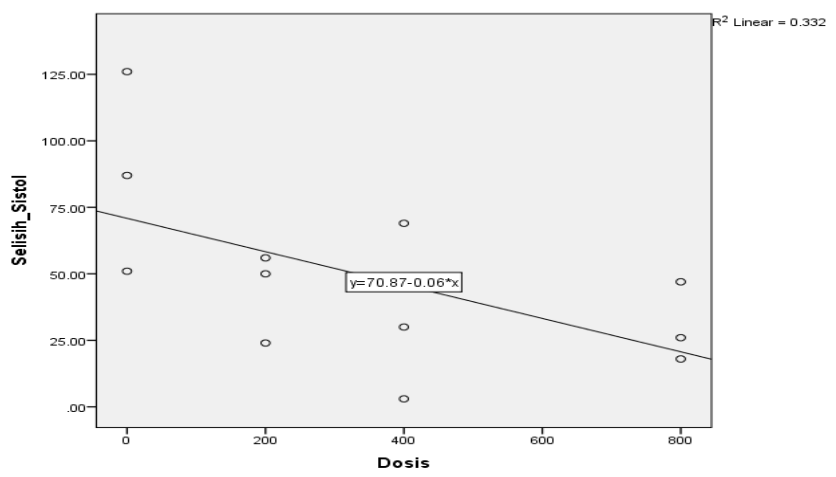

Fig 1. Systolic Blood Pressure Linear Test Graph

The process of hypertension can occur when rats with a high $\mathrm{NaCl}$ diet cause increased expression of the RAS system in the kidneys and brain which will stimulate renin secretion in renal juxtaglomerular cells. Activated renin converts angiotensinogen glycoprotein into angiotensin I. Angiotensin Converting Enzyme (ACE) converts Angiotensin I to produce Angiotensin II, whereas prednisone is an oral corticosteroid that has a glucocorticoid effect. 
Glucocorticoids which interact with glucocorticoid receptors in smooth and endothelial blood vessels which will increase the activation of AT- 1 receptors. Angiotensin II which binds to AT-1 and At-2 will induce aldosterone synthesis which will increase in plasma volume and blood pressure [9]-[11].

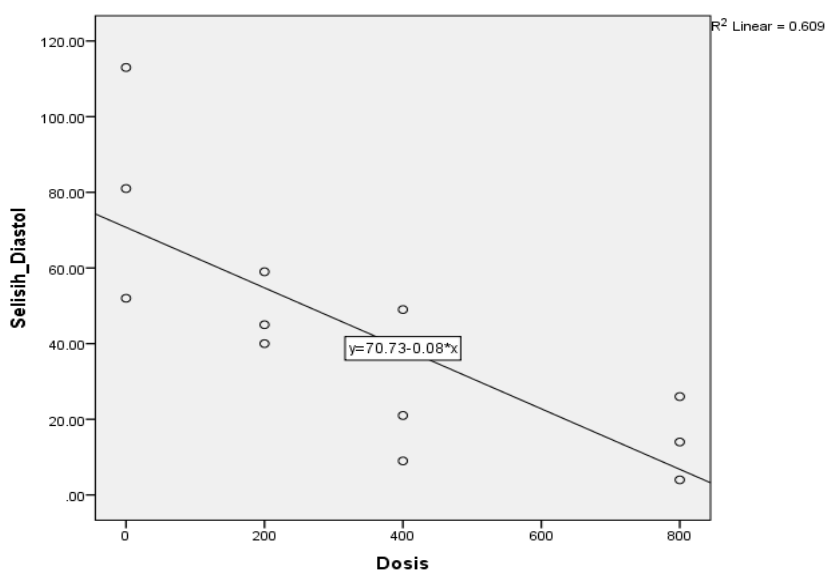

Fig 2. Diastolic Blood Pressure Linear Test Graph

Decrease blood pressure due to administration of bidara leaf extract is in accordance with [13], which said that saponin is an ingredient of bidara leaf extract can inhibit renin activity by suppressing the expression of the renin receptor in the RAAS system. Saponins, tannins, alkaloids and flavonoids which are the ingredients of bidara leaf extract are ACE inhibitors. Flavonoid compounds can also help lower blood pressure by increasing NO bioavailability by activating the e-NOS (endothelial Nitric Oxide Synthase) mechanism. E-NOS regulation will produce NO which acts as a powerful vasodilator which relaxed blood vessels and lowers blood pressure [13].

The histopathological improvement is in accordance as in [11] which showed that administration of ACE inhibitors can improve the histopathology of glomerulosclerosis by increasing the amount of plasmin by decreasing the expression of PAI-1 (Plasminogen Activator Inhibitor-1) which occurs due to a decrease in angiotensin II. The increase in plasmin levels will increase degradation of the extracellular matrix and lyse fibrin (matrix remodeling). In addition, ACE-inhibitors can also increase the intact glomerular capillary volume by $40 \%$ (capillary reorganization). [11] Saponin which is a content of bidara leas extract can suppress the expression of the renin receptor, namely PRR (Pro-Renin Receptor), inhibits the release of renin from granules, decrease the expression of TGF- $\beta$ gene expression will cause a decrease in PAI-1. Decrease in PAI-1 can cause an increase in plasmin levels [13]

\section{CONCLUSION}

The conclusion of this study was the bidara leaf extract (Ziziphus mauritiana) effective in reducing blood pressure in rats (Rattus novergicus strain wistar) hypertension model and remodelling glomerulosclerosis. The most effective dose of bidara leaf extract to reduce blood pressure and the amount of glomerulosclerosis in this study was $400 \mathrm{mg} / \mathrm{kgBW} /$ day

\section{ACKNOWLEDGMENT}

The authors would like to thank the medical students as well as research assistant. The researcher also wishes to thank
DPPM, University of Muhammadiyah Malang who funded this research and the BICMST committee for giving authors the opportunity to write this article.

\section{REFERENCES}

1. Bolivar, Juan J., Essential Hypertension: An Approach to Its Etiology and Neurogenic Pathophysiology, International Journal of Hypertension, 2013, pp 1-11.

2. Devadason, Pethuru, Risk Factors for Hypertension and its Complications - A Hospital Based Case Control Study, International Journal of Interdisciplinary and Multidisciplinary Studies, 1:4, 2014, pp. 160-163.

3. World Health Organization, a Global Brief on Hypertension World Health Day 2013 Silent Killer, Global Public Health Crisis, World Health Organization, 2013, pp. 1-40.

4. Health Research and Development Agency of The Indonesian Ministry of Health, Basic Health Research 2013, Riskesdas, 2013, pp. 1-268.

5. Udani, Suneel, Ivana Lazich, George L. Bakris, Epidemiology of Hypertensive Kidney Disease, Nature Reviews Nephrology, 7, 2011, pp.11-21

6. Gewin, Leslie, Roy Zent, How Does TGF- $\beta$ Mediate Tubulointerstitial Fibrosis, Seminars in Nephrology, 32 (3), 2012, pp. 228-235.

7. Mik, Sylvana ML., Pathophysiology and Treatment of Focal Segmental Glomerulosclerosis: The Role of Animal Models, Bio Med Central Nephrology, 14:74, 2013, pp.1-10.

8. Gupta, M.K., A. K. Bhandari, Ramesh Kumar Singh, Pharmacognostical Evaluations of the Leaves of Zizihus Mauritiana, International Journal of Pharmaceutical Science and Research, 3:3, 2012, pp. 818-821.

9. Duarte, J., V.Francisco, F. Perez-Vizcaino, Modulation of Nitric Oxide by Flavonoids, Food and Function, 5, 2014, pp. 1653-1668.

10. Jabeen, Qaiser, Naveed Aslam, Hypotensive, Angiotensin Converting Enzyme (ACE) Inhibitory and Diuretic Activities of the Aqueous-methanol Extract of Ipomoea reniformis, Iranian Journal of Pharmaceutical Research, 12 :4, 2013, pp. 769-776.

11. Yang, Hai-chun, Agnes B. Fogo, Mechanism of Disease Reversal in Focal and Segmental Glomerulosclerosis, National Kidney Foundation, 21:5, 2014, pp.442-447.

12. Purwanto, Bambang, Study of Expression TGF-b1, MMP-9,9, Collagen type-I,I, Collagen Type-IV, Glomerulosklerosis, Interstisial Fibrosis, Albuminuri in Doxorubicin Nefrotoksik and Nefroprotektif Pentoxifyllin with Experimental Animals in Swiss Male Mouse, Journal of Postgraduate Bioscience, 13:2, 2011, pp. 78-93.

13. Chen, M, Protective Effects of Saponin on a Hypertension Target Organ in Spontaneously Hypertensive Rats. Experimental and Therapeutic Medicine, Volume 5, 2013, pp. 429-432.

\section{AUTHORS PROFILE}

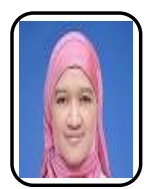

Dian Yuliarta Lestari is lecturer in Medical Faculty of Muhammadiyah Malang University. She completed his bachelor's degree at Brawijaya University in 2006, and postgraduate at Airlangga University in 2014. She is being pathologist since 2014. She often attended conferences on Medical Education and Anatomic Pathology at both national and international levels. She is interest about non communicable disease, herbal medicine and neoplasm. She already has publications in both national and international journals and proceedings.

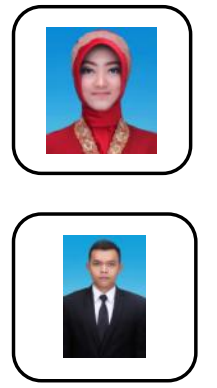

Cyntantya Pramastri Yuwono was born at 1997, she underwent medical education at the medical faculty of the University of Muhammadiyah Malang. She participated in the activities of the Scientico Medico student organization. She often follows lecturer research.

Dani Pratama Febrianto was born at 1997, he underwent medical education at the medical faculty of the University of Muhammadiyah Malang. He participated in the activities of the Scientico Medico student organization. He often follows lecturer research 